\title{
DISTRIBUTION OF STROKE RISK FACTORS IN EASTERN CROATIA
}

\author{
Bibijana Rostohar Bijelić ${ }^{1}$, Marta Petek ${ }^{2}$, Mira Kadojic ${ }^{3,4}$, \\ Nikola Bijelić ${ }^{4}$ and Dragutin Kadojić ${ }^{2,4}$ \\ ${ }^{1}$ Scientific Research Unit, Osijek University Hospital Centre, Osijek, Croatia; \\ ${ }^{2}$ University Department of Neurology, Osijek University Hospital Centre, Osijek, Croatia; \\ ${ }^{3}$ Department of Physical Medicine and Rehabilitation, Osijek University Hospital Centre, Bizovac, Croatia; \\ ${ }^{4}$ Faculty of Medicine, Josip Juraj Strossmayer University of Osijek, Osijek, Croatia
}

\begin{abstract}
SUMMARY - The aim of this study was to determine the distribution of risk factors according to age, gender, subtypes and recurrence of stroke in eastern Croatia. The study included 250 acute stroke patients admitted to University Department of Neurology, Osijek University Hospital Centre in 2011. Patients were grouped according to age, gender, subtypes and recurrence of stroke. The study showed significant differences in the distribution of cigarette smoking, diabetes, cardiomyopathy and hyperuricemia according to patient age. According to gender, male patients had a significantly higher prevalence of smoking and alcohol abuse, whereas in female patients the prevalence of arterial hypertension, atrial fibrillation and hyperuricemia was significantly higher. Regarding stroke subtypes, significant differences were noticed in the prevalence of arterial hypertension, atrial fibrillation, cardiomyopathy and cerebral blood vessel stenosis. Atrial fibrillation was significantly more common in first-ever than in recurrent stroke. Study results identified the groups of patients requiring special attention regarding particular risk factors in eastern Croatia and emphasized the need of developing regional strategies of screening, prevention and holistic care for stroke patients.
\end{abstract}

Key words: Stroke - epidemiology; Stroke - prevention and control; Risk factors; Hypertension; Cardiomyopathies; Smoking; Diabetes mellitus; Hyperuricemia; Croatia

\section{Introduction}

Stroke is one of the leading causes of death and disability all over the world ${ }^{1,2}$. The situation in Croatia is not different, since stroke is the second most common cause of death in Croatia ${ }^{3}$, and one of the most frequent cardiovascular diseases. Also, research shows that stroke has a significant influence on basic and specific daily life activities and interferes with the quality of life ${ }^{4}$. Despite major advancements in stroke management, prevention, i.e. modification of risk factors remains the best therapeutic approach ${ }^{5}$. There are some risk factors that are not subject to modification (age,

Correspondence to: Bibijana Rostohar Bijelic, MD, Vrbik 1, HR31000 Osijek, Croatia

E-mail: bibijana007@gmail.com

Received September 7, 2016, accepted December 11, 2017 gender and genetic constitution), however, many others are modifiable by behavior or therapy (smoking, obesity, lack of physical activity, healthy diet, arterial hypertension, hyperlipidemia and diabetes $)^{5-11}$.

Croatia is a small country with unique geographical and socio-cultural properties, where inland and Mediterranean Europe are interlaced; however, some dietary and lifestyle differences between its regions are present to date. With diet and lifestyle in view, Croatia can be divided into the inland and coastal regions. The inland part of Croatia has a greater burden of cardiovascular risk factors than the coastal part, which is most probably associated with the population lifestyle that greatly corresponds to that of Central and Eastern Europe. Many stroke risk factors are modifiable in this part of the world ${ }^{9,12}$. Several studies were carried out in order to determine differences in cardiovascular bur- 
den between geographical regions of Croatia, since these regions differ significantly in lifestyle, especially with regard to diet. Although results of these studies were somewhat different, it seems that the inland part, especially eastern Croatia, bears the greatest risk of cerebrovascular diseases ${ }^{12-14}$.

One of the major tendencies of modern medicine is individual approach to every patient, which definitely applies to stroke as well ${ }^{15,16}$. It is very important, since the previously mentioned risk factors, modifiable or not, are different for each patient suffering from stroke. Furthermore, since different regions within a country sometimes have different distribution of specific risk factors, the approach to prevention and treatment of stroke could be different on a regional basis. The distribution of risk factors is often different in urban and rural areas of a country too ${ }^{17,18}$. Better understanding and good records of the distribution of these factors that contribute to the onset of stroke may help in developing guidelines for regional and individualized strategies in fighting this debilitating disease. Therefore, the aim of this research was to determine the distribution of stroke risk factors in several defined groups in order to determine the possible special patterns of their distribution. Such patterns should help determine the need of special attention to some groups of patients according to the most frequent risk factors for stroke in a particular group. The results obtained can be compared to those from other parts of Croatia and other countries, which can be helpful in the evaluation of previous approach and improvement of further screening, prevention and holistic care for stroke patients in this region and wider.

\section{Patients and Methods}

The study included 250 acute stroke patients treated at University Department of Neurology, Osijek University Hospital Centre in 2011. In all patients, the diagnosis of stroke was confirmed by computed tomography $(\mathrm{CT})$ of the brain. All patients underwent electrocardiography (ECG), transcranial Doppler (TCD) and color Doppler flow imaging (CDFI). TCD was performed in order to evaluate stenoses of intracranial parts of vertebral arteries, basilar artery, initial parts of frontal, middle and posterior cerebral arteries, carotid siphon, and terminal part of internal carotid artery. CDFI was used in stenosis evaluation of extracranial
Table 1. Clinical characteristics of study patients

\begin{tabular}{|l|l|}
\hline \multicolumn{2}{|l|}{ Study group, N=250 } \\
\hline Clinical characteristic & $\mathrm{n}(\%)$ \\
\hline Female & $120(48.0)$ \\
Male & $130(52.0)$ \\
First-ever stroke & $174(69.6)$ \\
Recurrent stroke & $76(30.4)$ \\
Type of stroke: & \\
$\quad$ hemorrhagic & $29(11.6)$ \\
$\quad$ ischemic & $221(88.4)$ \\
\hline Age (yrs), mean (range) & $71.58(42-96)$ \\
\hline
\end{tabular}

parts of internal carotid and vertebral arteries. The structure of study group according to age, gender, type and recurrence of stroke is shown in Table 1.

Patients were classified into three groups according to age as follows: patients aged $<50$, patients aged $50-$ 79 and patients aged $\geq 80$. Patients were also divided according to gender and stroke subtype. For hemorrhagic stroke, the subtypes were hypertensive intracerebral hemorrhage (ICHh), atypical intracerebral hemorrhage (ICHa), and subarachnoid hemorrhage (SAH). Since there were only 7 cases of ICHa and $\mathrm{SAH}$, they were not included in the analysis (too small sample). For ischemic stroke, subtypes were defined according to the TOAST (Trial of Org 10172 in Acute Stroke Treatment) classification: large vessel stroke (LVS), small vessel stroke (SVS), cardioembolic stroke (CES), other type of stroke (OS), and undetermined stroke (US) ${ }^{19}$. In addition, patients were divided on the basis of suffering a first-ever stroke (FES) or recurrent stroke (RES). The interval between FES and RES was not recorded and analyzed; nevertheless, the distribution of risk factors was analyzed for each of these two groups as well.

In all groups, the prevalence of the following risk factors was investigated: arterial hypertension, high cholesterol, high triglycerides, high cholesterol and triglycerides, cigarette smoking (present at the time of arrival), diabetes, alcohol abuse, atrial fibrillation, cardiomyopathy, other cardiogenic factors (myocardial infarction, valvular insufficiency and angina pectoris), hyperuricemia, and cerebral blood vessel stenosis (stenosis was considered as more than $50 \%$ reduction of blood vessel lumen, both intracranial and extracranial; all degrees were included). 
Table 2. Distribution of risk factors according to age groups

\begin{tabular}{|c|c|c|c|c|}
\hline \multirow{4}{*}{ Risk factor } & \multicolumn{3}{|c|}{ Age group (years) } & \multirow{4}{*}{$\begin{array}{l}\mathrm{p} \\
\text { value }\end{array}$} \\
\hline & $<50$ & $50-79$ & $\geq 80$ & \\
\hline & $\mathrm{n}=10$ & $\mathrm{n}=185$ & $\mathrm{n}=55$ & \\
\hline & $\mathrm{n}(\%)$ & n (\%) & n (\%) & \\
\hline $\begin{array}{l}\text { Arterial } \\
\text { hypertension }\end{array}$ & $7(70.0)$ & $150(81.1)$ & $49(89.0)$ & 0.214 \\
\hline High cholesterol & $3(30.0)$ & $44(23.8)$ & $15(27.3)$ & 0.748 \\
\hline $\begin{array}{l}\text { High } \\
\text { triglycerides }\end{array}$ & $1(10.0)$ & $16(8.7)$ & $1(1.8)$ & 0.163 \\
\hline $\begin{array}{l}\text { High cholesterol } \\
\text { and triglycerides }\end{array}$ & $3(30.0)$ & $47(25.4)$ & $11(20.0)$ & 0.607 \\
\hline $\begin{array}{l}\text { Cigarette } \\
\text { smoking }\end{array}$ & $4(40.0)$ & 34 (18.4) & $3(5.5)$ & 0.007 \\
\hline Diabetes & $2(20.0)$ & $57(30.8)$ & $8(14.6)$ & 0.043 \\
\hline Alcohol abuse & $0(0.0)$ & $24(13.0)$ & $3(5.5)$ & 0.204 \\
\hline Atrial fibrillation & $0(0.0)$ & 27 (14.6) & $14(25.5)$ & 0.060 \\
\hline $\begin{array}{l}\text { Cardio- } \\
\text { myopathy }\end{array}$ & $0(0.0)$ & $42(22.7)$ & 19 (34.6) & 0.034 \\
\hline $\begin{array}{l}\text { Other } \\
\text { cardiogenic } \\
\text { factors }\end{array}$ & $1(10.0)$ & $22(11.9)$ & $8(14.6)$ & 0.864 \\
\hline $\begin{array}{l}\text { Hyper- } \\
\text { uricemia }\end{array}$ & $1(10.0)$ & $45(24.3)$ & $23(41.8)$ & 0.018 \\
\hline $\begin{array}{l}\text { Cerebral blood } \\
\text { vessel stenosis }\end{array}$ & $4(40.0)$ & $68(36.8)$ & $19(34.6)$ & 0.937 \\
\hline
\end{tabular}

Other cardiogenic factors = myocardial infarction, valvular insuffi ciency, angina pectoris

Statistical analysis was performed using SPSS 13.0 for Windows. Distribution of risk factors (shown in Tables 2-5) was analyzed using Fisher exact test. The values of $\mathrm{p}<0.05$ were considered significant. The study was approved by the relevant ethics committee.

\section{Results}

The study showed significant differences in the distribution of cigarette smoking, diabetes, cardiomyopathy and hyperuricemia according to patient age. The prevalence of cigarette smoking declined with age, diabetes was most common in the 50-79 age group, and the prevalence of cardiomyopathy and hyperuricemia increased with age (Table 2).

Significant differences were also found in the distribution of arterial hypertension, cigarette smoking,
Table 3. Distribution of risk factors according to gender

\begin{tabular}{|l|l|l|l|}
\hline \multirow{2}{*}{ Risk factor } & \multicolumn{2}{|c|}{ Gender } & \multirow{2}{*}{} \\
\cline { 2 - 3 } & $\begin{array}{l}\text { Male } \\
\mathrm{n}=130\end{array}$ & $\begin{array}{l}\text { Female } \\
\mathrm{n}=120\end{array}$ & p value \\
\cline { 2 - 3 } & $\mathrm{n}(\%)$ & $\mathrm{n}(\%)$ & \\
\hline Arterial hypertension & $100(76.9)$ & $106(88.3)$ & 0.020 \\
High cholesterol & $31(23.9)$ & $31(25.8)$ & 0.770 \\
High triglycerides & $11(8.5)$ & $7(5.8)$ & 0.471 \\
High cholesterol & $29(22.3)$ & $32(26.7)$ & 0.463 \\
and triglycerides & $31(23.9)$ & $10(8.3)$ & 0.001 \\
Cigarette smoking & $35(26.9)$ & $32(26.7)$ & $>0.950$ \\
Diabetes & $25(19.2)$ & $2(1.7)$ & $<0.001$ \\
$\begin{array}{l}\text { Alcohol abuse } \\
\text { Atrial fibrillation }\end{array}$ & $13(10.0)$ & $28(23.3)$ & 0.006 \\
Cardiomyopathy & $23(17.7)$ & $28(31.7)$ & 0.277 \\
$\begin{array}{l}\text { Other cardiogenic } \\
\text { factors }\end{array}$ & $20(15.4)$ & $11(9.2)$ & 0.179 \\
Hyperuricemia & $28(21.5)$ & $41(34.2)$ & 0.033 \\
$\begin{array}{l}\text { Cerebral blood vessel } \\
\text { stenosis }\end{array}$ & $51(39.2)$ & $40(33.3)$ & 0.359 \\
\hline
\end{tabular}

Other cardiogenic factors = myocardial infarction, valvular insufficiency, angina pectoris

alcohol abuse, atrial fibrillation and hyperuricemia between male and female patients. Male patients had a significantly higher prevalence of smoking and alcohol abuse $(23.9 \%$ vs. $8.3 \%$ and $19.2 \%$ vs. $1.7 \%$, respectively), whereas the prevalence of arterial hypertension, atrial fibrillation and hyperuricemia was significantly higher in female patients (88.3\% vs. $76.9 \%, 23.3 \%$ vs. $10 \%$ and $34.2 \%$ vs. $21.5 \%$, respectively) (Table 3).

Regarding stroke subtypes, significant differences were recorded in the prevalence of arterial hypertension, atrial fibrillation, cardiomyopathy and cerebral blood vessel stenosis. Nearly all patients with CES and only $67.8 \%$ of patients with LVS had arterial hypertension. Compared with other subtypes, the prevalence of atrial fibrillation was about 10 times higher and the prevalence of cardiomyopathy highest in patients with CES. The prevalence of cerebral blood vessel stenosis was highest in the SVS group, followed by CES and LVS (Table 4).

There was no significant difference in the distribution of risk factors between FES and RES, except for atrial fibrillation, which was significantly more common in FES (19.5\% vs. 9.2\%) (Table 5). 
Table 4. Distribution of risk factors in most common stroke subtypes

\begin{tabular}{|c|c|c|c|c|c|}
\hline \multirow{3}{*}{ Risk factor } & \multicolumn{4}{|c|}{ Stroke subtype } & \multirow{3}{*}{$\mathrm{p}$ value } \\
\hline & $\begin{array}{l}\text { ICHh } \\
n=22\end{array}$ & $\begin{array}{l}\text { LVS } \\
\mathrm{n}=59\end{array}$ & $\begin{array}{l}\text { SVS } \\
n=106\end{array}$ & $\begin{array}{l}\text { CES } \\
n=31\end{array}$ & \\
\hline & n (\%) & n (\%) & n (\%) & $\mathrm{n}(\%)$ & \\
\hline Arterial hypertension & $20(90.9)$ & $40(67.8)$ & $90(84.9)$ & $30(96.8)$ & 0.002 \\
\hline High cholesterol & $5(22.7)$ & $16(27.1)$ & $23(21.7)$ & $10(32.3)$ & 0.623 \\
\hline High triglycerides & $1(4.5)$ & $7(11.9)$ & $9(8.5)$ & $0(0.0)$ & 0.212 \\
\hline $\begin{array}{l}\text { High cholesterol } \\
\text { and triglycerides }\end{array}$ & $3(13.6)$ & $11(18.6)$ & $34(32.1)$ & $7(22.6)$ & 0.142 \\
\hline Cigarette smoking & $2(9.1)$ & $8(13.6)$ & $20(18.9)$ & $4(12.9)$ & 0.676 \\
\hline Diabetes & $4(18.2)$ & $15(25.4)$ & $29(27.4)$ & $11(35.5)$ & 0.576 \\
\hline Alcohol abuse & $1(4.5)$ & $10(16.9)$ & $13(12.3)$ & $1(3.2)$ & 0.207 \\
\hline Atrial fibrillation & $1(4.5)$ & $5(8.5)$ & $8(7.5)$ & $24(77.4)$ & $<0.001$ \\
\hline Cardiomyopathy & $0(0.0)$ & $10(16.9)$ & $28(26.4)$ & $14(45.2)$ & $<0.001$ \\
\hline Other cardiogenic factors & $3(13.6)$ & $6(10.2)$ & $16(15.1)$ & $2(6.5)$ & 0.590 \\
\hline Hyperuricemia & $8(36.4)$ & $14(23.7)$ & $27(25.5)$ & $14(45.2)$ & 0.117 \\
\hline Cerebral blood vessel stenosis & $2(9.1)$ & $20(33.9)$ & $46(43.4)$ & $11(35.5)$ & 0.016 \\
\hline
\end{tabular}

$\mathrm{ICHh}=$ hypertensive intracerebral hemorrhage; LVS = large vessel stroke; SVS = small vessel stroke; CES = cardioembolic stroke; other cardiogenic factors = myocardial infarction, valvular insufficiency, angina pectoris

Table 5. Distribution of risk factors in first-ever and recurrent stroke

\begin{tabular}{|c|c|c|c|}
\hline \multirow{3}{*}{ Risk factor } & \multicolumn{2}{|c|}{ Stroke } & \multirow{3}{*}{$\mathrm{p}$ value } \\
\hline & \multirow{2}{*}{\begin{tabular}{|l|}
$\begin{array}{l}\text { First-ever } \\
\mathrm{n}=174\end{array}$ \\
$\mathrm{n}(\%)$
\end{tabular}} & \multirow{2}{*}{\begin{tabular}{|l|}
$\begin{array}{l}\text { Recurrent } \\
\mathrm{n}=76\end{array}$ \\
$\mathrm{n}(\%)$
\end{tabular}} & \\
\hline & & & \\
\hline Arterial hypertension & $142(81.6)$ & $64(84.2)$ & 0.719 \\
\hline High cholesterol & $45(25.9)$ & $17(22.4)$ & 0.634 \\
\hline High triglycerides & $12(6.9)$ & $6(7.9)$ & 0.793 \\
\hline $\begin{array}{l}\text { High cholesterol } \\
\text { and triglycerides }\end{array}$ & $42(34.1)$ & $19(25.0)$ & 0.874 \\
\hline Cigarette smoking & $27(15.5)$ & $14(18.4)$ & 0.581 \\
\hline Diabetes & $42(24.1)$ & $25(32.9)$ & 0.164 \\
\hline Alcohol abuse & $20(11.5)$ & $7(9.2)$ & 0.664 \\
\hline Atrial fibrillation & $34(19.5)$ & $7(9.2)$ & 0.043 \\
\hline Cardiomyopathy & $41(23.6)$ & $20(26.3)$ & 0.635 \\
\hline $\begin{array}{l}\text { Other cardiogenic } \\
\text { factors }\end{array}$ & $18(10.3)$ & $13(17.1)$ & 0.148 \\
\hline Hyperuricemia & $49(28.2)$ & $20(26.3)$ & 0.878 \\
\hline $\begin{array}{l}\text { Cerebral blood vessel } \\
\text { stenosis }\end{array}$ & $64(36.8)$ & $27(35.5)$ & 0.887 \\
\hline
\end{tabular}

Other cardiogenic factors = myocardial infarction, valvular insuffi ciency, angina pectoris

\section{Discussion}

The study revealed certain differences between the examined groups, some of them significant. Regarding age, there were significant differences in the distribution of four risk factors: cigarette smoking, diabetes, cardiomyopathy and hyperuricemia. Cigarette smoking was most frequent in the group of patients aged $<50$, diabetes in the group of patients aged 50-79, and cardiomyopathy and hyperuricemia in the group of patients aged $\geq 80$. Hence, certain age groups have their specific risk factor to pay special attention to. Some researchers report the prevalence of arterial hypertension to be $39.3 \%$ in young ( $<50$ years) stroke patients ${ }^{20}$, whereas in our group it was $70.0 \%$, which is quite high compared to the aforementioned results. This result emphasizes the need for greater efforts to be invested in screening for and treating of hypertension in the population below 50 years of age, i.e. before stroke occurs. Also, in the group of young patients there was a higher prevalence of diabetes mellitus than in the study mentioned previously. On the other hand, the prevalence of alcohol abuse and atrial fibrillation was lower, while the prevalence of cigarette smoking was approximately the same ${ }^{20}$. However, our $<50$ age 
group was rather small, so this figure should be taken with caution.

According to gender, some significant differences were recorded. Female patients had a higher prevalence of arterial hypertension, atrial fibrillation and hyperuricemia, while male patients had a higher prevalence of cigarette smoking and alcohol abuse. This is interesting because it shows a somewhat larger impact of lifestyle in male than in female patients. Results of other investigators are partly contradictory concerning gender differences and risk factors for stroke. Considering our results, the situation is similar, i.e. some of them are in line with other researches, and some are quite opposite. For example, the higher prevalence of arterial hypertension in female patients was also found in several studies ${ }^{3,21-23}$, whereas other studies report no gender difference with regard to hypertension, or found a higher prevalence of hypertension in males ${ }^{24,25}$.

When patients were divided according to subtypes of stroke, significant differences were detected in the prevalence of arterial hypertension, atrial fibrillation, cardiomyopathy and cerebral blood vessel stenosis. In case of atrial fibrillation and cardiomyopathy, these differences reflect the pathophysiological mechanisms underlying CES, since atrial fibrillation and cardiomyopathy contribute to embolus formation. Hence, patients suffering from atrial fibrillation have a significantly greater risk of cardioembolic stroke ${ }^{7}$. Also, hypertension and atrial fibrillation are known to be associated with an increased risk of death within one year after stroke ${ }^{26}$, and their prevalence was significantly higher in patients suffering from CES. That is why this subtype of ischemic stroke has poorer prognosis and demands more effort in risk factor control.

Regarding RES and FES, there were no significant differences except for one risk factor, atrial fibrillation, which was more common in FES. This indicates that screening and prevention measures should be taken in consideration $^{8}$, especially in the 50-79 age group, before FES occurs. Besides this, in RES patients, diabetes and other cardiogenic factors were more frequent, indicating that better control of these diseases is mandatory ${ }^{6}$.

Although all risk factors require attention in the prevention of stroke, our research suggests that the prevention of stroke and its risk factors should be adjusted to different population groups. For example, in the group below 50 years of age, emphasis should be on the prevention of smoking, in the group between 50 and 79 years of age on diabetes, atrial fibrillation and alcohol abuse prevention, screening and treatment, and in the group of 80 years of age and above, special attention should be paid to cardiomyopathy and hyperuricemia. Arterial hypertension, atrial fibrillation and hyperuricemia are the risk factors of special interest in females, and smoking and alcohol abuse in males. Among ischemic stroke subtypes, prevention of CES requires special efforts, since it is the subtype with the poorest outcome and prognosis ${ }^{7}$. Regarding risk factors in FES and RES, the same preventive measures are required in both cases. Since arterial hypertension remains the predominant risk factor for stroke, primary and secondary prevention of this disease has to be viewed as a public health priority, since reducing the prevalence of arterial hypertension would also mean reducing the risk of stroke in eastern Croatian population $^{13}$. Cadilhac et al. report on successful methods of primary and secondary prevention of $\operatorname{stroke}^{27}$ that could be applied elsewhere, including eastern Croatia.

Different prevention and therapeutic strategies in different regions of the same country may sometimes be required. This should mean that region-specific campaigns and other types of prevention may be established on a local or regional basis, for example, in eastern Croatia. Urban and rural differences should also be taken into account. Since we lack such information, we also suggest investigating whether relevant differences in stroke risk factors and stroke recurrence exist between stroke patients coming from rural and urban parts of eastern Croatia. Data such as those set forth in this research might motivate and help in defining local and individualized strategies for prevention and treatment of serious public health problems such as stroke. For example, in eastern Croatia it is evident that more effort should be invested in the prevention of important risk factors, for example, in the form of public campaigns for hypertension prevention, early detection of diabetes and atrial fibrillation, or campaigns that promote healthy but economic lifestyle. Primary and secondary prevention through the work of general practitioners could also be even more driven by regional needs. If research like this one would be repeated on a regular basis, it would represent an aid in further advancement of the regional care for stroke patients. Such efforts might be the first steps in establishing different regional models of stroke prevention 
and care and their implementation in everyday practice.

In conclusion, this research highlighted the specific groups of patients that require special attention regarding their risk factors in eastern Croatia. The need is stressed of re-evaluating the stroke risk factor management and developing regional strategies of screening, prevention and holistic care for stroke patients. Such efforts can be applied nationwide and beyond.

\section{Acknowledgment}

The study was supported by the Ministry of Science, Education and Sports of the Republic of Croatia, grant No. 127-0000000-3421.

\section{References}

1. O’Donnell MJ, Chin SL, Rangarajan S, Xavier D, Liu L, Zhang H, et al.; INTERSTROKE investigators. Global and regional effects of potentially modifiable risk factors associated with acute stroke in 32 countries (INTERSTROKE): a casecontrol study. Lancet Lond Engl. 2016;388(10046):761-75. doi: 10.1016/S0140-6736(16)30506-2.

2. Farhoudi M, Mehrvar K, Sadeghi-Bazargani H, Hashemilar M, Seyedi-Vafaee M, Sadeghi-Hokmabad E, et al. Stroke subtypes, risk factors and mortality rate in northwest of Iran. Iran J Neurol. 2017;16(3):112-7.

3. Bašić Kes V, Jurašić M-J, Zavoreo I, Lisak M, Jelec V, Zadro Matovina L. Age and gender differences in acute stroke hospital patients. Acta Clin Croat. 2016;55(1):69-78. doi: 10.20471/acc.2016.55.01.11.

4. Jeon NE, Kwon KM, Kim YH, Lee JS. The factors associated with health-related quality of life in stroke survivors aged 40 and older. Ann Rehabil Med. 2017;41(5):743-52. doi: 10.5535/arm.2017.41.5.743.

5. Boehme AK, Esenwa C, Elkind MSV. Stroke risk factors, genetics, and prevention. Circ Res. 2017;120(3):472-95. doi: 10.1161/CIRCRESAHA.116.308398.

6. Otite FO, Liaw N, Khandelwal P, Malik AM, Romano JG, Rundek T, et al. Increasing prevalence of vascular risk factors in patients with stroke: a call to action. Neurology. 2017;89 (19):1985-94. doi: 10.1212/WNL.0000000000004617.

7. Pistoia F, Sacco S, Tiseo C, Degan D, Ornello R, Carolei A. The epidemiology of atrial fibrillation and stroke. Cardiol Clin. 2016;34(2):255-68. doi: 10.1016/j.ccl.2015.12.002.

8. Boriani G, Proietti M. Atrial fibrillation prevention: an appraisal of current evidence. Heart Br Card Soc. 2017. doi: 10.1136/heartjnl-2017-311546.

9. Pikija S, Trkulja V, Malojcic B, Mutzenbach JS, Sellner J. A high burden of ischemic stroke in regions of Eastern/Central
Europe is largely due to modifiable risk factors. Curr Neurovasc Res. 2015;12(4):341-52. doi: $10.2174 / 1567202612666150731105554$.

10. Oza R, Rundell K, Garcellano M. Recurrent ischemic stroke: strategies for prevention. Am Fam Physician. 2017;96(7): 436-40.

11. Kjeldsen SE. Hypertension and cardiovascular risk: general aspects. Pharmacol Res. 2017;S1043-6618(17)31118-0. doi: 10.1016/j.phrs.2017.11.003.

12. Bergman Marković B, Vrdoljak D, Kranjčević K, Vučak J, Kern J, Bielen I, et al. Continental-Mediterranean and rural-urban differences in cardiovascular risk factors in Croatian population. Croat Med J. 2011;52:566-75. doi: $10.3325 / \mathrm{cmj} .2011 .52 .566$.

13. Uhernik AI, Erceg M, Mihel S. Risk of angina pectoris, nonfatal myocardial infarction and non-fatal stroke among hypertensives: the CroHort study. Coll Antropol. 2012;36 Suppl 1: 135-8.

14. Kadojić D, Dikanović M, Bitunjac M, Vuletić V, Čengić L, Rostohar Bijelić B. Epidemiology of stroke. Period Biol. 2012;114:253-7.

15. Polívka J, Rohan V, Sevčík P, Polívka J. Personalized approach to primary and secondary prevention of ischemic stroke. EPMA J. 2014;5(1):9. doi: 10.1186/1878-5085-5-9.

16. Hayes DF, Markus HS, Leslie RD, Topol EJ. Personalized medicine: risk prediction, targeted therapies and mobile health technology. BMC Med. 2014;12:37. doi: 10.1186/1741-7015-12-37.

17. Nakibuuka J, Sajatovic M, Nankabirwa J, Furlan AJ, Kayima J, Ddumba E, et al. Stroke risk factors differ between rural and urban communities: population survey in Central Uganda. Neuroepidemiology. 2015;44(3):156-65. doi: $10.1159 / 000381453$.

18. Lindroth M, Lundqvist R, Lilja M, Eliasson M. Cardiovascular risk factors differ between rural and urban Sweden: the 2009 Northern Sweden MONICA cohort. BMC Public Health. 2014;14:825. doi: 10.1186/1471-2458-14-825.

19. Adams HP, Bendixen BH, Kappelle LJ, Biller J, Love BB, Gordon DL, et al. Classification of subtype of acute ischemic stroke. Definitions for use in a multicenter clinical trial. TOAST. Trial of Org 10172 in Acute Stroke Treatment. Stroke. 1993;24 (1):35-41. doi: 10.1161/01.STR.24.1.35.

20. Putaala J, Haapaniemi E, Kaste M, Tatlisumak T. How does number of risk factors affect prognosis in young patients with ischemic stroke? Stroke. 2012;43(2):356-61. doi: 10.1161/STROKEAHA.111.635276.

21. Giralt D, Domingues-Montanari S, Mendioroz M, Ortega L, Maisterra O, Perea-Gainza M, et al. The gender gap in stroke: a meta-analysis. Acta Neurol Scand. 2012;125(2):83-90. doi: 10.1111/j.1600-0404.2011.01514.

22. Yu C, An Z, Zhao W, Wang W, Gao C, Liu S, et al. Sex differences in stroke subtypes, severity, risk factors, and outcomes 
among elderly patients with acute ischemic stroke. Front Aging Neurosci [Internet]. 2015 Sep 8 [cited 2017 Dec 7];7:174. doi: 10.3389/fnagi.2015.00174.

23. Morović S, Rundek T, Demarin V. Gender differences in stroke. Period Biol. 2012;114(3):267-8.

24. Ahangar AA, Saadat P, Heidari B, Taheri ST, Alijanpour S. Sex difference in types and distribution of risk factors in ischemic and hemorrhagic stroke. Int J Stroke. 2017;17474993017724626. doi: 10.1177/1747493017724626.

25. Petrea RE, Beiser AS, Seshadri S, Kelly-Hayes M, Kase CS, Wolf PA. Gender differences in stroke incidence and post- stroke disability in the Framingham Heart Study. Stroke. 2009;40(4):1032-7. doi: 10.1161/STROKEAHA.108.542894.

26. Liu X, Xu G, Wu W, Zhang R, Yin Q, Zhu W. Subtypes and one-year survival of first-ever stroke in Chinese patients: the Nanjing Stroke Registry. Cerebrovasc Dis Basel Switz. 2006; 22(2-3):130-6. doi: 10.1159/000093241.

27. Cadilhac DA, Kilkenny MF, Johnson R, Wilkinson B, Amatya B, Lalor E. The Know Your Numbers (KYN) program 2008 to 2010: impact on knowledge and health promotion behavior among participants. Int J Stroke Off J Int Stroke Soc. 2015; 10(1):110-6. doi: 10.1111/ijs.12018.

Sažetak

\section{RASPODJELA RIZIČNIH ČIMBENIKA ZA MOŽDANI UDAR U ISTOČNOJ HRVATSKOJ}

\section{B. Rostohar Bijelic, M. Petek, M. Kadojić, N. Bijelić i D. Kadojić}

Cilj ovoga istraživanja bio je odrediti raspodjelu rizičnih čimbenika u bolesnika s moždanim udarom u istočnoj Hrvatskoj prema dobi, spolu, podtipovima i ponovnom javljanju. U istraživanje bilo je uključeno 250 bolesnika koji su pretrpjeli akutni moždani udar i primljeni su na Kliniku za neurologiju Kliničkoga bolničkog centra Osijek u 2011. godini. Bolesnici su podijeljeni prema dobi, spolu, podtipovima i ponovnom javljanju. Istraživanje je pokazalo značajne razlike u raspodjeli pušenja cigareta, dijabetesa, kardiomiopatije i hiperuricemije prema dobi bolesnika. Prema spolu, učestalost pušenja i zlouporabe alkohola bila je značajno veća kod muških bolesnika, dok je učestalost arterijske hipertenzije, atrijske fibrilacije i hiperuricemije bila značajno veća kod žena. Prema podtipovima moždanog udara, značajne razlike uočene su kod učestalosti arterijske hipertenzije, atrijske fibrilacije, kardiomiopatije i stenoze cerebralnih krvnih žila. Atrijska fibrilacija bila je značajno češća u prvom nego u ponovljenom moždanom udaru. Naši rezultati pokazuju koje skupine bolesnika u istočnoj Hrvatskoj zahtijevaju posebnu pozornost s obzirom na pojedine rizične čimbenike te naglašavaju potrebu osmišljavanja regionalnih strategija za probir, prevenciju i holističku brigu za oboljele od moždanog udara.

Ključne riječi: Moždani udar-epidemiologija; Moždani udar - prevencija i kontrola; Rizični čmbenici; Hipertenzija; Kardiomiopatije; Pušenje; Dijabetes melitus; Hiperuricemija; Hrvatska 